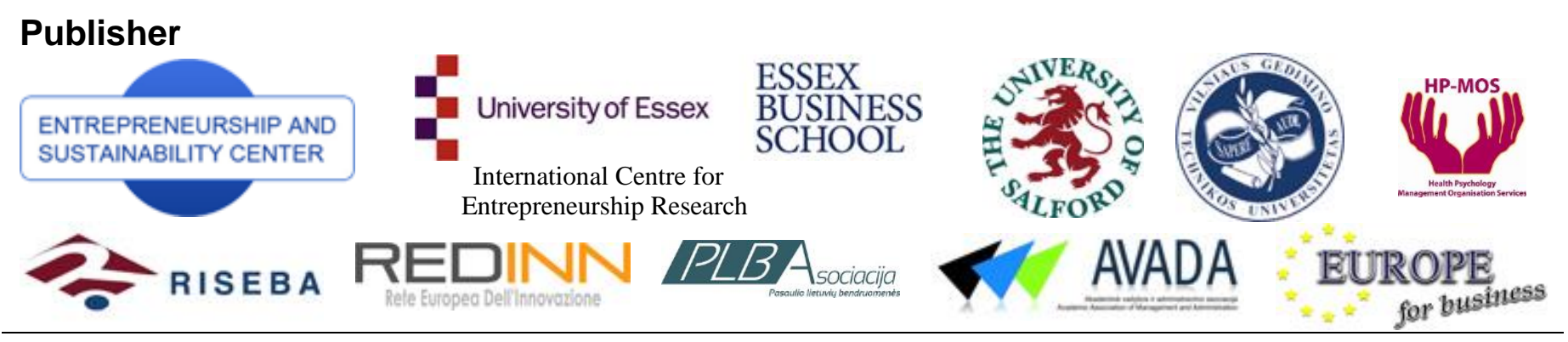

The International Journal

ENTREPRENEURSHIP AND SUSTAINABILITY ISSUES

ISSN 2345-0282 (online) http://jssidoi.org/jesi/aims-and-scope-of-research/

2016 Volume 3 Number 3 (March)

\title{
START-UPS ACROSS THE EU: IF PARTICULAR TENDENCIES COULD BE TRACED
}

\author{
Manuela Tvaronavičienè \\ Vilnius Gediminas Technical University, Sauletekio 11, LT-10223 Vilnius, Lithuania \\ E-mail:manuela.tvaronaviciene@vgtu.lt
}

Received 20 November 2015; accepted 15 January 2016

\begin{abstract}
The aim of presented paper is to provide interpretation of available statistical data on entrepreneurship processes in European countries. The author seeks to find answer the question if new business development processes are active and successful what consistent patterns (if any) could be traced. Success factors, such as education and age of entrepreneurs, which launched start-ups in European countries are taken in to accounts. Obtained results, it is believed, would contribute for understanding entrepreneurship phenomena in differently developed countries and, respectively, for finding ways how more efficiently to foster inception of successful and sustainable ventures in the nearest future.
\end{abstract}

Keywords: youth unemployment, sustainability, the Analytic Hierarchy Process (AHP).

Reference to this paper should be made as follows: Tvaronavičienè, M. 2016. Start-ups across the EU: if particular tendencies could be traced, Entrepreneurship and Sustainability Issues 290-298.

DOI: http://dx.doi.org/10.9770/jesi.2016.3.3(6)

JEL Classifications: M21

\section{Introduction}

Development of entrepreneurship has become an important aim of each country. Encouraging potential entrepreneurs to take this life path became one the most important task of educators and governments across the EU and other countries (Njaramba et al. 2015; Matetskaya 2015; Tunčikienè, Drejeris 2015; Rosha, Lace, 2015; Dobele et al. 2015).

Entrepreneurship has received a lot of definitions. We would adopt one of vast array, rather simple, but at the same time reflecting its spirit. We support the following definition: " entrepreneurship is ability to pull not necessarily available resources in order to fill in a gap in market and meet demand for goods and services of certain quality". Another nonconflicting definitions is: " entrepreneurs can create demand for certain goods or services by suggesting novel products or services, which attract customers". We could continue on by looking for better definitions, but we tackle now a different issue. Since each idea, opportunity has to be implemented through business entity, we want to find out how those young business companies or start-ups are doing in various European countries, and what common characteristics of those companies could be provided. We wonder if available data could be systemized and if particular general tendencies could be traced. 


\section{Methodology}

In order to characterize entrepreneurial activity in European countries and possibly generalize contemporary practices, the metrics of such activity have to be set.

We adopt the following approach to the research. At first, we intend to search for available statistics on entrepreneurship subject. The second, out of available indicators, we will chose those, which to our opinion would be suitable for providing information about tendencies of development of entrepreneurial entities in countries of different development level. The third, we intend to clarify what profile of entrepreneurs is the most common, if any.

\section{The context}

Search of entrepreneurship data allowed to come to following insights: data on entrepreneurship in European counties is rather sporadic, it is impossible to provide trends, since values of one indicators are available for one years, while values for another indicators are available for another years; sequence is not maintained.

Before we take a closer look at the most valuable available data, let us clarify, what particular data is attributed to entrepreneurship statistics and how it differs from statistics of small and medium enterprises (SMEs). Statistics on SMEs, their role in economy is attributed to so called "structural business statistics". As Eurostat indicates, "Structural business statistics can be analysed by enterprise size class (defined in terms of the number of persons employed). The overwhelming majority (99.8\%) of enterprises active within the EU-28's non-financial business economy in 2012 were micro, small and medium-sized enterprises (SMEs) - some 22.3 million — together they contributed $57.5 \%$ of the value added generated within the EU's non-financial business economy. More than 9 out of $10(92.7 \%)$ enterprises in the EU28 were micro enterprises (employing less than 10 persons) and their share of value added within the non-financial business economy was considerably lower, around one fifth. Perhaps the most striking phenomenon of SMEs is their contribution to employment. No less than two thirds (67.1\%) of the EU's non-financial business economy workforce was active in an SME in 2012. Some 23.4 million persons worked in SMEs in the distributive trades sector, 17.8 million in manufacturing and 11.1 million in construction; together, these three activities provided work to $58.2 \%$ of the nonfinancial business economy workforce in SMEs. Micro enterprises employed more people than any other enterprise size class in all service sectors (at the section level of detail), with the exception of administrative and support service activities. This pattern was particularly pronounced for the repair of computers, personal and household goods where an absolute majority of the workforce in this sector worked in micro enterprises. By contrast, in mining and quarrying as well as electricity, gas, steam and air conditioning supply large enterprises employed more than half of the workforce, as they also did in administrative and support service activities.

The contribution of SMEs to non-financial business economy value added was lower than their contribution to employment, resulting in a lower level of apparent labour productivity. This pattern was particularly prevalent among activities such as manufacturing or information and communication services. However, it was also observed across most other activities, the exceptions were: administrative and support service activities; and electricity, gas, steam and air conditioning. As a result, large enterprises tended to record higher apparent labour productivity ratios than SMEs." (Source: Eurostat (http://ec.europa.eu/eurostat/statisticsexplained/index.php/Structural_business_statistics_overview)

Above presented citation from Eurostat provides a clear picture of SMEs role in economy, which is being reflected by structural business statistics. Entrepreneurship statistics, which we intend to tackle, in Eurostat is called "Business demography" since it provides data on

- the active population of enterprises; 
- their birth;

- $\quad$ survival (followed up to five years after birth),

- death.

As Eurostat reports, "business demography data has been collected on a voluntary basis since 2002“; ,activities relating to industry, construction, distributive trades and services are covered, but agriculture, public administration, non-market activities of households, and extra-territorial agencies are not" (Source:

http://ec.europa.eu/eurostat/web/structural-business-statistics/entrepreneurship/business-demography). Voluntary basis of data explains why available data is sporadic, as it was observed above.

Now let us examine available data and provide their scientific interpretation.

\section{Analysis and interpretation of available data}

Let us start our analysis from birth rate of companies, which is provided in Table 1, Fig. 1. The birth rate is provided as ratio, what gives us rather clear picture of propensity to start a new business or, to put it into another way, to incept a startup. Data is available only for 6 countries for year 2014. Even basing on this information rather interesting insights could be formulated: Bulgaria, Latvia and Estonia demonstrate considerably higher propensity to start business if to compare to such developed countries as Belgium and Germany. We could draw a conclusion that more developed countries demonstrate lower propensity to start a new business due to mature markets, high competition and, especially, high opportunity costs. Such insight seems to be sufficiently logical, judging from theoretical point of view and could be treated as particular tendency or consistent pattern if not Estonia's data. According this insight Estonia's propensity to engage into new business should by similar to its Baltic neighbors - Lithuania and Estonia, meanwhile according available data Estonia more resembles behavior of Germany, despite maturity of markets in those countries differs considerably. What suppress Estonia's willingness to develop small business remains obscure.

Table 1. Birth rate: number of enterprise births in the reference period $(\mathrm{t})$ divided by the number of enterprises active in $t$

(Industry, construction and services except insurance activities of holding companies)

\begin{tabular}{|l|l|l|l|l|}
\hline $\begin{array}{l}\text { GEO/ } \\
\text { SIZECLAS }\end{array}$ & Total & $\begin{array}{l}\text { From 1 to } \\
\text { employees }\end{array}$ & $\begin{array}{l}\text { From 5 to } \\
9 \\
\text { employees }\end{array}$ & $\begin{array}{l}10 \\
\text { employees } \\
\text { or more }\end{array}$ \\
\hline Belgium & 2,96 & 3,88 & 1,23 & 0,67 \\
\hline Bulgaria & 12,34 & 15,94 & 4,62 & 2,3 \\
\hline $\begin{array}{l}\text { Germany (until 1990 former territory of } \\
\text { the FRG) }\end{array}$ & 7,03 & 10,36 & 1,76 & 0,61 \\
\hline Estonia & 7,43 & 9,72 & 2,53 & 0,94 \\
\hline Latvia & 12,6 & 16,76 & 7,19 & 1,97 \\
\hline Lithuania & 12,52 & 18,64 & 5,87 & 2,51 \\
\hline
\end{tabular}

Source: Eurostat, year 2014 (retrieved year 2016)

Another peculiar insight can be made about size of start-ups. Graphical reflection of available data (Fig.1) allow us to conclude that especially small companies of size from 1 to 4 employees dominate irrespective to country, in which company is started. 


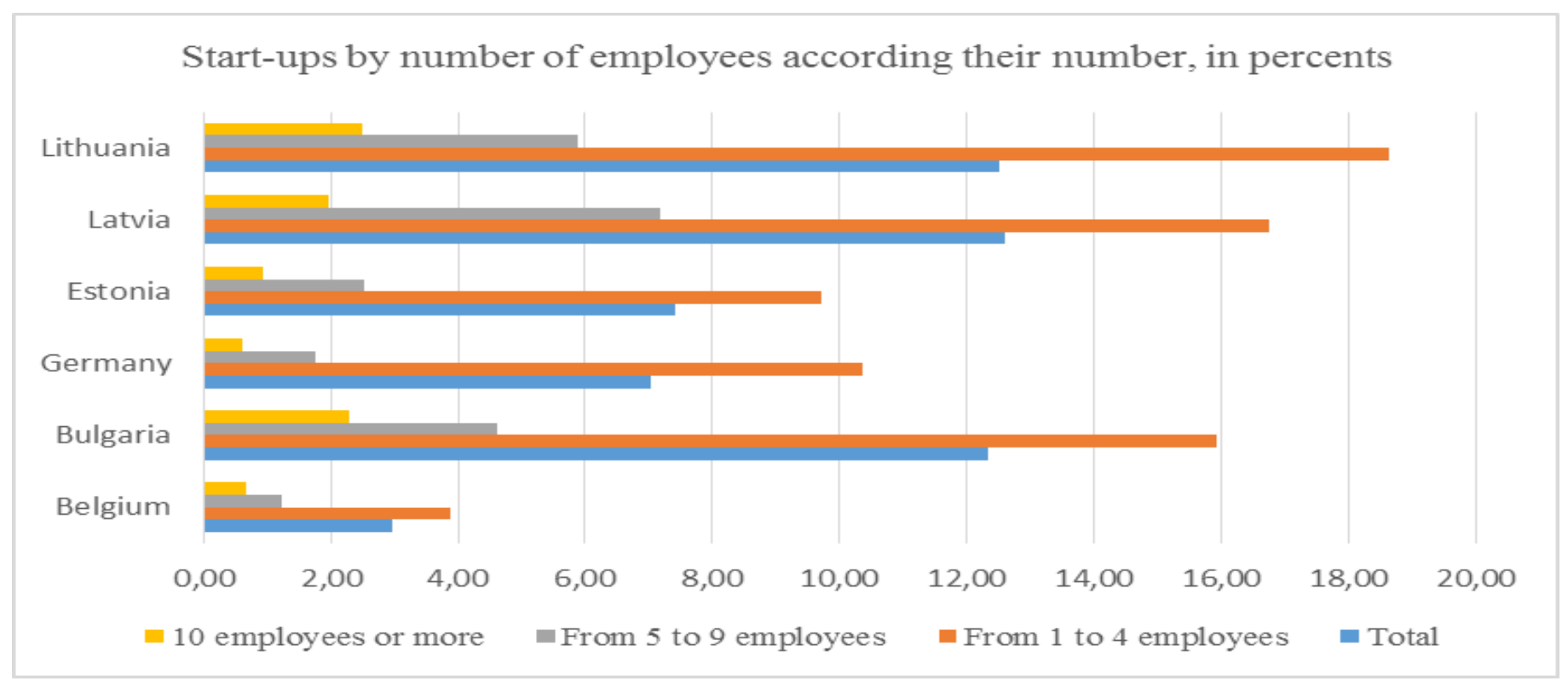

Fig. 1. Birth rate: number of enterprise births in the reference period $(\mathrm{t})$ divided by the number of enterprises active in $\mathrm{t}$ Industry, construction and services except insurance activities of holding companies Source: author, based on data from Eurostat, year 2014 (retrieved in year 2016)

After having formed impression about entrepreneurial behavior in listed above countries let us examine what kind of companies survive after 3 years of performance. It is a pity we cannot take the same countries and use statistics about their entrepreneurship statistics. We use statistics available, which provide us with data not exactly compatible with data we discussed above. Anyway, we believe that trends, generalized using scientific theories, basics of microeconomics, macroeconomics, industrial economics, organizational theories and entrepreneurship theory and practice, which is in possession of the writer of this paper would lead to insights, which have a potential to trigger responsive discussion and contribute to economics and management science.

Hence, critically observing and juxtaposing data, provided by Eurostat for listed below countries, year 2015 (Table 2), we can come to the following insights (see below Table 2). 


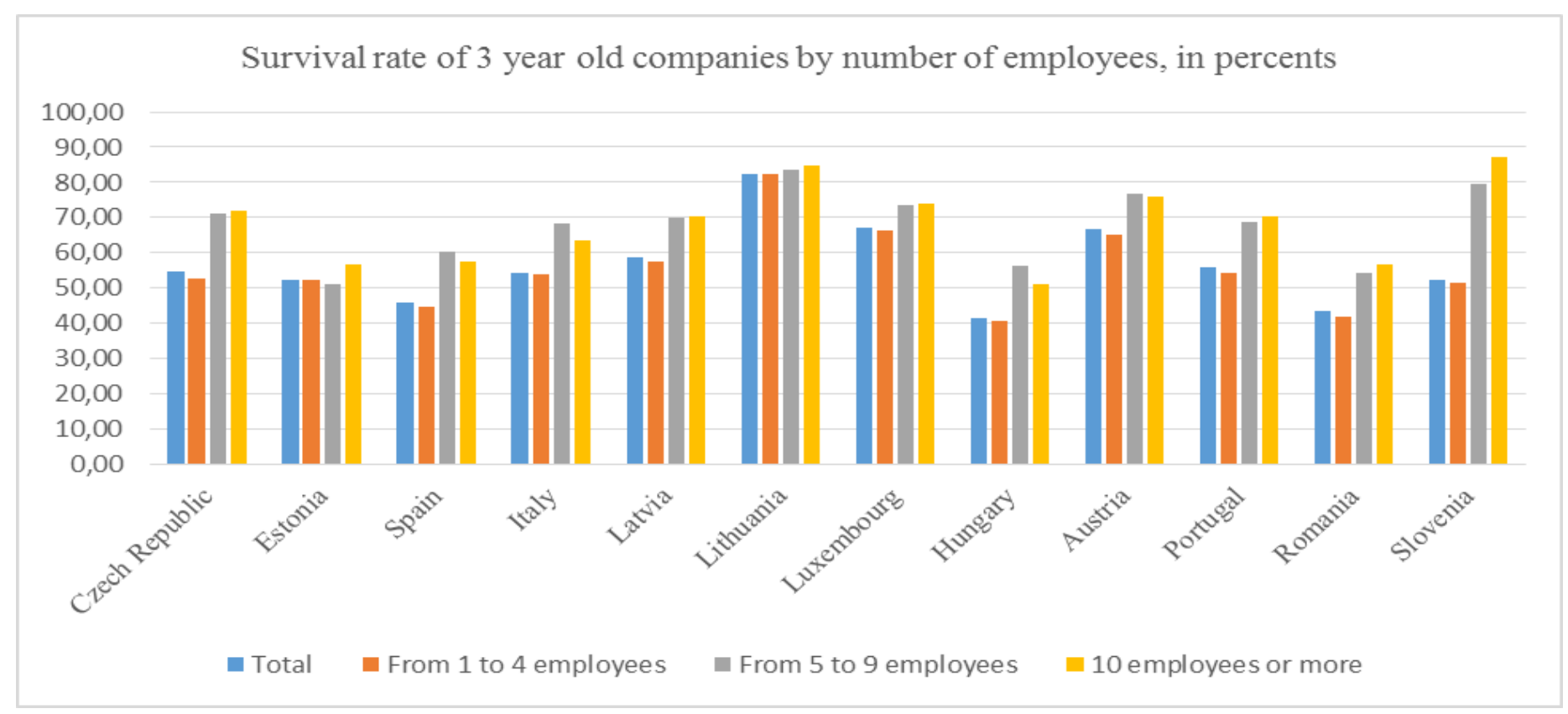

Fig. 2. Survival rate 3: number of enterprises in the reference period ( $t$ ) newly born in $t-3$ having survived to $t$ divided by the number of enterprise births in $\mathrm{t}-3$

Source: author, based on data from Eurostat, last update year 2015(retrieved in year 2016)

Survival rates of different size companies suggest an insight that bigger companies (10 employees or more) have the greater chance to proceed if to compare to the smallest companies (from 1 to 4 employees). What is peculiar, that this tendency is characteristic to absolutely all 12 countries, for which data is available. Let us recall a conclusion, which was suggested above: paradoxically entrepreneurs are more prone to start the smallest companies, while, as it appears, they have lower chances to survive.

If to comment on general level of probability to survive for start-ups irrespective of size expressed in percentage terms across the countries of different development, we need to admit that consistent patterns are invisible. According available data, in Lithuania and Slovenia chances to survive are the highest (data for year 2015). Again particular tendencies, which would be characteristic for better developed and less developed countries are not traceable.

Factors of success, Propensity to innovate, ability be creative and ability to cooperate with another companies and, especially universities requires not only literacy, financial literacy, but formal education as well (Ignatavičius et al. 2015; Tvaronavičienė et al. 2015a, 2015b; Tvaronavičienè, Černevičiūtè 2015; Rezk et al. 2015). Certain level of education serves as one of success factors (Laužikas, Mokšeckienė2013; Dzemyda, Raudeliūnienè 2014; Rosha, Lace 2015; Lace et al. 2015; Branten, Purju 2015; Njaramba et al. 2015; Matetskaya 2015). Level of education of startups across European countries is provided in Table 3 . 
Table 3. Enterprises managed by the founder - by education of the entrepreneur (Industry and services)

\begin{tabular}{|c|c|c|c|c|c|c|c|c|c|}
\hline $\begin{array}{l}\text { GEO/ } \\
\text { ISCED97 }\end{array}$ & $\begin{array}{l}\text { All } \\
\text { ISCED } \\
1997 \\
\text { levels }\end{array}$ & $\begin{array}{l}\text { Primary } \\
\text { and lower } \\
\text { secondary } \\
\text { education } \\
\text { (levels } 1 \\
\text { and 2) }\end{array}$ & $\begin{array}{l}\text { Primary } \\
\text { and lower } \\
\text { secondary } \\
\text { education } \\
\text { (levels } 1 \\
\text { and } 2 \text { )<\% }\end{array}$ & $\begin{array}{l}\text { Upper } \\
\text { secondary } \\
\text { education } \\
\text { (level 3) }\end{array}$ & $\begin{array}{l}\text { Upper } \\
\text { secondary } \\
\text { education } \\
\text { (level 3), } \\
\%\end{array}$ & $\begin{array}{l}\text { Post- } \\
\text { secondary } \\
\text { non- } \\
\text { tertiary } \\
\text { education } \\
\text { (level 4) }\end{array}$ & $\begin{array}{l}\text { Post- } \\
\text { secondary } \\
\text { non- } \\
\text { tertiary } \\
\text { education } \\
\text { (level 4), } \\
\% \\
\end{array}$ & $\begin{array}{l}\text { First and } \\
\text { second } \\
\text { stage of } \\
\text { tertiary } \\
\text { education } \\
\text { (levels } 5 \\
\text { and 6) } \\
\end{array}$ & $\begin{array}{l}\text { First and } \\
\text { second } \\
\text { stage of } \\
\text { tertiary } \\
\text { education } \\
\text { (levels } 5 \\
\text { and 6),\% }\end{array}$ \\
\hline $\begin{array}{l}\text { European } \\
\text { Union }\end{array}$ & $\begin{array}{l}202 \\
048 \\
\end{array}$ & 37689 & 19 & 55794 & 28 & 65545 & 32 & 43019 & 21 \\
\hline Bulgaria & 25918 & 481 & 2 & 8943 & 35 & 4400 & 17 & 12094 & 47 \\
\hline $\begin{array}{l}\text { Czech } \\
\text { Republic }\end{array}$ & 18362 & 998 & 5 & 9397 & 51 & 2294 & 12 & 5673 & 31 \\
\hline Denmark & 7433 & 1660 & 22 & 1543 & 21 & 1248 & 17 & 2982 & 40 \\
\hline Estonia & 2582 & 62 & 2 & 400 & 15 & 548 & 21 & 1572 & 61 \\
\hline Italy & 37449 & 13340 & 36 & 18403 & 49 & 722 & 2 & 4984 & 13 \\
\hline Latvia & 7939 & 139 & 2 & 2972 & 37 & 844 & 11 & 3984 & 50 \\
\hline Lithuania & 7704 & 67 & 1 & 947 & 12 & 1531 & 20 & 5159 & 67 \\
\hline Luxembourg & 2871 & 1564 & 54 & 432 & 15 & 441 & 15 & 434 & 15 \\
\hline Austria & 15088 & 602 & 4 & 4476 & 30 & 4241 & 28 & 5768 & 38 \\
\hline Portugal & 49319 & 26173 & 53 & 11574 & 23 & 2993 & 6 & 8580 & 17 \\
\hline Romania & 71054 & 16356 & 23 & 4576 & 6 & 49156 & 69 & 966 & 1 \\
\hline Slovenia & 2168 & 94 & 4 & 807 & 37 & 578 & 27 & 689 & 32 \\
\hline Slovakia & 10249 & 1539 & 15 & 4877 & 48 & 351 & 3 & 3482 & 34 \\
\hline Sweden & 5920 & 1082 & 18 & 2200 & 37 & 1161 & 20 & 1477 & 25 \\
\hline
\end{tabular}

Source: Eurostat, last update year 2011(retrieved in year 2016)

Available data suggests that entrepreneurs with rather differing level of education rather similarly engage in new businesses development; average data is marked in green. Data which fall out general context highlighted in yellow. It should be mentioned that in Luxembourg and Portugal more than half start-ups in year 2011 was run by entrepreneurs with primary and lower education, meanwhile in Lithuania and Estonia 67 and respectively 61 percent of start-ups was managed by especially educated entrepreneurs - with the first and second stage of tertiary education. Despite data is too sporadic to suggest generalizations, but anyway association is that the more educated entrepreneurs start more sophisticated businesses with the higher potential to survive. Let us recall that Lithuania with the best educated entrepreneurs demonstrates the highest rates of start-ups survival.

Experience of entrepreneurs as well is attributed to factors of success. Graphical reflection of available data across European countries is presented in Figure 3. It is obvious that mature entrepreneurs (40 years or over) prevail in all European countries irrespective of their development level. 


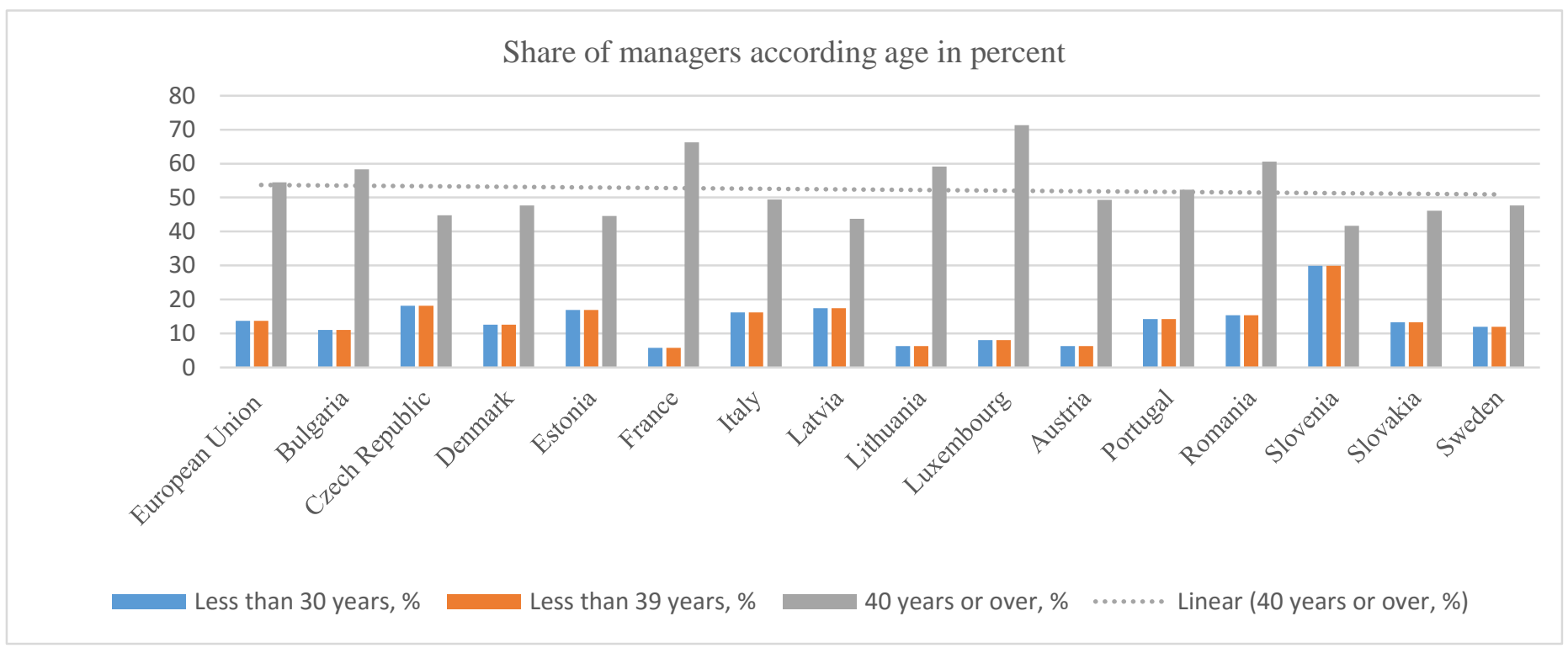

Fig. 3. Percentage share of start-up managers attributed to three age groups: less than 30 years old, in-between 30 and 40 years, and, respectively, 40 years or over.

Source: author, based on data from Eurostat, last update year 2005 (retrieved in year 2016)

This paper represent attempts to integrate rather fragmented data into a concise picture of start-up phenomena in European countries. Of course, the process is much more complex and is impacted by numerous factors, which were not discussed in this paper (e.g. (Laužikas et al. 2015; Tunčikienè, Drejeris 2015; Grubicka, Matuska 2015; Akhmadeev, Manakhov 2015; Kalyugina et al. 2015). Anyway, despite of indicated research limitations, the some particular tendencies of startups development across European counties have been traced.

\section{Conclusions}

Answering a question raised at the very beginning of this paper about particular tendencies of start-ups demography and success factors, such as entrepreneurs' profiles in terms of their education level and age, we can indicate the following findings.

The first, we claim, that more developed countries demonstrate lower propensity to start a new business due to mature markets, high competition and, especially, high opportunity costs. Such insight seems to be sufficiently logical, judging from theoretical point of view and could be treated as particular tendency or consistent pattern if not Estonia's data

The second peculiar insight can be made about size of start-ups. Graphical reflection of available data allow us to conclude that especially small companies of size from 1 to 4 employees dominate irrespective to country, in which company is started.

The third, the survival rates of different size companies suggest an insight that bigger companies (10 employees or more) have the greater chance to proceed if to compare to the smallest companies (from 1 to 4 employees). What is peculiar, that this tendency is characteristic to absolutely all 12 countries, for which data is available. 
The fourth, despite data is too sporadic to suggest generalizations, but anyway association is that the more educated entrepreneurs start more sophisticated businesses with the higher potential to survive. Let us recall that Lithuania with the best educated entrepreneurs demonstrates the highest rates of start-ups survival.

And the fifth, ultimately, we noticed that mature entrepreneurs (40 years or over) prevail in all European countries irrespective of their development level.

Formulated insights, we believed, could be verified further by employing bigger pools of data, when they are available, and, ultimately formulated insights could be contribute to generalization of entrepreneurial practice and contribute to more efficient policy formulations.

\section{References}

Akhmadeev, B.; Manakhov, S. 2015 Effective and sustainable cooperation between start-ups, venture investors, and corporations, Journal of Security and Sustainability Issues 5(2): 269-284. DOI:http://dx.doi.org/10.9770/jssi.2015.5.2(12)

Branten, E.; Purju, A. 2015. Cooperation projects between university and companies: process of formation and objectives of the stakeholders, Entrepreneurship and Sustainability Issues 3(2):149-156. DOI: http://dx.doi.org/10.9770/jesi.2015.3.2(3)

Dobele, L.; Grinberga-Zalite, G.; Kelle, L. 2015. Sustainable economic development: scenarios for promotion of social innovation in Latvia, Journal of Security and Sustainability Issues 5(2): 149-158. DOI: http://dx.doi.org/10.9770/jssi.2015.5.2(2)

Dzemyda, I.; Raudeliūnienè, J. 2014. Sustainable youth entrepreneurship in conditions of global economy toward energy security, Entrepreneurship and Sustainability Issues 1(4): 247-256. DOI: http://dx.doi.org/10.9770/jesi.2014.1.4(7)

Eurostat; http://ec.europa.eu/eurostat

Grubicka, J.; Matuska, E. 2015. Sustainable entrepreneurship in conditions of UN (Safety) and technological convergence, Entrepreneurship and Sustainability Issues 2(4):188-197. DOI: http://dx.doi.org/10.9770/jesi.2015.2.4(2)

Ignatavičius, R.; Tvaronavičienè, M.; Piccinetti, L. 2015. Sustainable development through technology transfer networks: case of Lithuania, Journal of Security and Sustainability Issues 4(3): 261-267. DOI: http://dx.doi.org/10.9770/jssi.2015.4.3(6)

Kalyugina, S.; Strielkowski, W.; Ushvitsky, L.; Astachova, E. 2015. Sustainable and secure development: facet of personal financial issues, Journal of Security and Sustainability Issues 5(2): 297-304. DOI: http://dx.doi.org/10.9770/jssi.2015.5.2(14)

Lace, N.; Natalja, Buldakova, N.; Rumbinaite, G. 2015. Organizational creativity as a driving force for company's innovative development, Entrepreneurship and Sustainability Issues 3(2): 137-148. DOI: http://dx.doi.org/10.9770/jesi.2015.3.2(2)

Laužikas, M.; Mokšeckienè, R. 2013. The role of creativity in sustainable business, Entrepreneurship and Sustainability Issues 1(1): 10-22. DOI: http://dx.doi.org/10.9770/jesi.2013.1(2)

Laužikas, M.; Tindale, H.; Augustinas Bilota, A.; Dovilė Bielousovaitė, D. 2015. Contributions of sustainable start-up ecosystem to dynamics of start-up companies: the case of Lithuania, Entrepreneurship and Sustainability Issues 3(1): 8-24. DOI:http://dx.doi.org/10.9770/jesi.2015.3.1(1)

Matetskaya, M. 2015. Education programmes for entrepreneurs in the creative industries in St. Petersburg, Entrepreneurship and Sustainability Issues 3(1): 66-73. DOI: http://dx.doi.org/10.9770/jesi.2015.3.1(6)

Matetskaya, M. 2015. Education programmes for entrepreneurs in the creative industries in St. Petersburg, Entrepreneurship and Sustainability Issues 3(1): 66-73. DOI:http://dx.doi.org/10.9770/jesi.2015.3.1(6) 
Njaramba, J.; Chigeza, P.; Whitehouse, H. 2015. Financial literacy:the case of migrant African-Australian women entrepreneurs in the $\begin{array}{lll}\text { cairns } & \text { region, Entrepreneurshipand } & \text { Sustainability }\end{array}$ DOI: http://dx.doi.org/10.9770/jesi.2015.3.2(7)

Njaramba, J.; Chigeza, P.; Whitehouse, H. 2015. Financial literacy:the case of migrant African-Australian women entrepreneurs in the cairns region, Entrepreneurship and

DOI: http://dx.doi.org/10.9770/jesi.2015.3.2(7)

Rezk, M. R. A.; Ibrahim, H., H.; Tvaronavičiené, M.; Sakr, M. M.; Piccinetti, L. 2015.Measuring innovations in Egypt: case of industry, Entrepreneurship and Sustainability Issues 3(1): 47-55. DOI: http://dx.doi.org/10.9770/jesi.2015.3.1(4)

Rosha, A.; Lace, N. 2015. Sustainable development of organizations: coaching for innovation accelerating, Journal of Security and Sustainability Issues 5(2): 171-180. DOI: http://dx.doi.org/10.9770/jssi.2015.5.2(4)

Tunčikienė, Ž.;Drejeris, R. 2015. Entrepreneurship ecosystem: methodological approaches to functions' review of public sector institutions, Entrepreneurship and Sustainability Issues 2(3):118-132. DOI: http://dx.doi.org/10.9770/jesi.2014.2.3(1)

Tvaronavičienė M.; Razminienè, K.; Piccinetti, L. 2015.b. Cluster efficiency study through benchmarking, Entrepreneurship and Sustainability Issues 3(2):120-128. DOI: http://dx.doi.org/10.9770/jesi.2015.3.2(0)

Tvaronavičienè, M., Razminienè, K., Piccinetti, L. 2015a, Aproaches towards cluster analysis, Economics and Sociology, 8(1): 19-27. DOI: 10.14254/2071-789X.2015/8-1/2 http://www.economics-sociology.eu/files/ES Vol8 1 Tvaronavicien\%C4\%97.pdf

Tvaronavičienė, M.; Černevičiūtè, J. 2015. Technology transfer phenomenon and its impact on sustainable development, Journal of Security and Sustainability Issues 5(1): 87-97. DOI: http://dx.doi.org/10.9770/jssi.2015.5.1(7)

Manuela TVARONAVIČIENĖ is dr, professor at Vilnius Gediminas Technical University and The General Jonas Žemaitis Military Academy of Lithuania. Here research interests are: sustainable development, innovations, investments, entrepreneurship. She raised qualifications in USA, Canada, and Europe in various institutions, including such as IESE Business School of Navarra University, Harvard Business School of Harvard University, and Judge College of Cambridge University.

This is an open access journal and all published articles are licensed under a

Creative Commons Attribution 4.0 International License

Copyright of Journal "Entrepreneurship and Sustainability Issues" (C) Entrepreneurship and Sustainability Center, All Rights Reserved 